\title{
Author Correction: SARS-CoV-2 uses metabotropic glutamate receptor subtype 2 as an internalization factor to infect cells
}

Jinliang Wang, Guan Yang, Xinxin Wang, Zhiyuan Wen, Lei Shuai, Jie Luo, Chong Wang (D, Ziruo Sun, Renqiang Liu, Jinying Ge, Xijun He, Ronghong Hua, Xijun Wang, Xiao Yang, Weiye Chen, Gongxun Zhong (D and Zhigao Bu

Correction to: Cell Discovery (2021) 7:119

https://doi.org/10.1038/s41421-021-00357-z

published online 14 December 2021

In the original publication of this article ${ }^{1}$, we made some mistakes in Fig. 4c and d. The layer of nucleus was missing in the images of CK5 and CK8 of Fig. 4c, and the layer of Ace2 was shifted in the image of Ace2 of Fig. 4d. The correctly labelled Fig. 4c and d are displayed as below. This correction does not affect the results or the conclusion of this work.

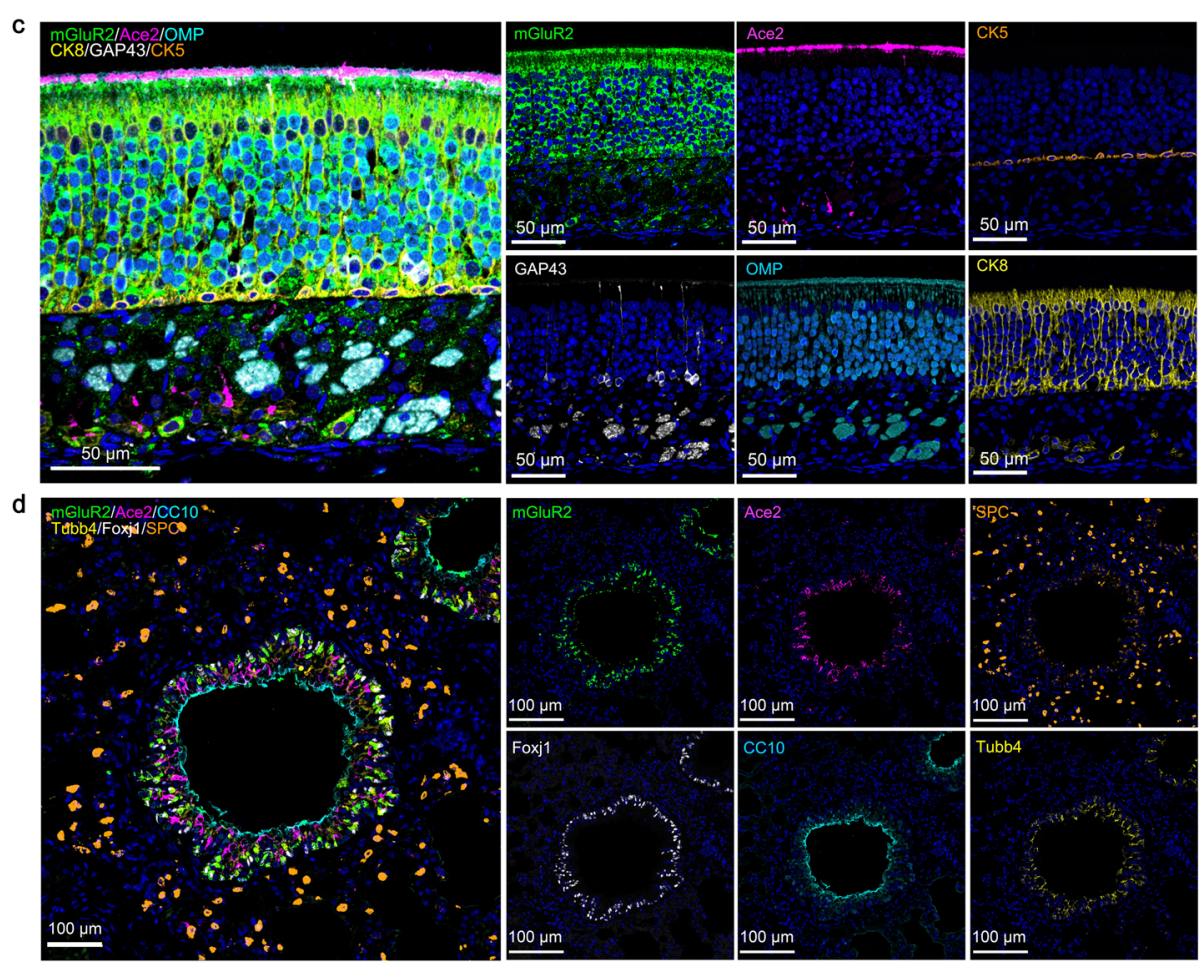

(c) The Author(s) 2021

(c) (i) Open Access This article is licensed under a Creative Commons Attribution 4.0 International License, which permits use, sharing, adaptation, distribution and reproduction cc. in any medium or format, as long as you give appropriate credit to the original author(s) and the source, provide a link to the Creative Commons license, and indicate if changes were made. The images or other third party material in this article are included in the article's Creative Commons license, unless indicated otherwise in a credit line to the material. If material is not included in the article's Creative Commons license and your intended use is not permitted by statutory regulation or exceeds the permitted use, you will need to obtain permission directly from the copyright holder. To view a copy of this license, visit http://creativecommons.org/licenses/by/4.0/. 
Published online: 27 December 2021
Reference

1. Wang, J. et al. SARS-CoV-2 uses metabotropic glutamate receptor subtype 2 as an internalization factor to infect cells. Cell Discov. 7, 119 (2021). 